NBER WORKING PAPER SERIES

\title{
DID EXPANDING MEDICAID AFFECT WELFARE PARTICIPATION?
}

John C. Ham

Lara D. Shore-Sheppard

Working Paper 9803

http://www.nber.org/papers/w9803

\section{NATIONAL BUREAU OF ECONOMIC RESEARCH 1050 Massachusetts Avenue Cambridge, MA 02138}

June 2003

We would like to thank Eileen Kopchik and Noam Yuchtman for excellent research assistance, and the National Institute of Child Health and Human Development (Grant No. R01 HD39369-01A1) and the National Science Foundation (Grant No. SBR-9809546) for financial support. We are grateful to Aaron Yelowitz for making his programs and data available for our use. We received helpful comments from seminar participants at the Orley Ashenfelter Festschrift and Williams. The views expressed in this paper in no way represent those of the NSF or NICHD. The views expressed herein are those of the authors and not necessarily those of the National Bureau of Economic Research.

C2003 by John C. Ham and Lara D. Shore-Sheppard. All rights reserved. Short sections of text not to exceed two paragraphs, may be quoted without explicit permission provided that full credit including (C) notice, is given to the source. 
Did Expanding Medicaid Affect Welfare Participation?

John C. Ham and Lara D. Shore-Sheppard

NBER Working Paper No. 9803

June 2003

JEL No. I38, I18

\section{$\underline{\text { ABSTRACT }}$}

Using data from the 1988-1996 Current Population Surveys (CPS), we re-examine the evidence presented in Yelowitz (1995) showing that expansions in Medicaid eligibility for children were associated with increased labor force participation and reduced participation in Aid to Families with Dependent Children (AFDC) among single mothers. We find that Yelowitz's results were the result of two factors. First, he imposed a strong restriction on the parameter estimates that is not predicted by theory and is rejected in the CPS data. Second, he used only one of the two income tests that families must pass to be eligible for AFDC, resulting in higher imputed AFDC breakeven income levels for larger families. Once these problems are addressed, the Medicaid income limits have no significant effect on AFDC participation. The AFDC income limits, however, are significantly related to welfare and labor force participation in both his original sample and the entire 1988-1996 sample.

John C. Ham

Department of Economics Arps Hall, 1945 N. High Street

Ohio State University

Columbus, $\mathrm{OH} 43210$

JOHNHAM@ecolan.sbs.ohio-state.edu
Lara D. Shore-Sheppard

Department of Economics

Fernald House, 34 Sawyer Library Drive Williams College

Williamstown, MA 01267

and NBER

Lara.D.Shore-Sheppard@williams.edu 
With the advent of "welfare reform" in 1996, which replaced the Aid to Families with Dependent Children (AFDC) program with Temporary Assistance to Needy Families (TANF), there has been strong interest in factors that help single-headed families leave cash assistance. One factor that has received some attention is the link between cash assistance and publiclyprovided health insurance (Medicaid). Until the late 1980s, virtually the only way for a lowincome woman or child to receive Medicaid was to participate in AFDC. Since leaving AFDC meant losing one's health insurance as well as cash support, and since many low-wage jobs do not offer health insurance, the connection between AFDC and Medicaid provided an additional incentive for a woman to remain on welfare, even if she might otherwise choose to participate in the labor force.

Beginning in the late 1980s, however, Medicaid coverage was expanded to children in families with incomes well above the AFDC limits. Separate Medicaid eligibility income limits were established that were linked to the poverty line rather than to a state's AFDC limits, permitting children in low-income working-parent families to qualify for Medicaid despite their family's ineligibility for AFDC. This break in the link between AFDC and Medicaid for children has potentially made it easier for families to leave welfare, since at least some of the children in the families can keep their health insurance following an exit from welfare. In this paper, we investigate how breaking the link between AFDC participation and Medicaid eligibility affected labor market outcomes for single mothers. Specifically, we examine whether the availability of Medicaid coverage for a woman's children unconnected to AFDC led to increased labor force participation and reduced welfare participation. This issue is particularly relevant for current policy, since under TANF, Medicaid eligibility determination is separate from cash assistance 
eligibility determination. Thus it is possible that an individual could be eligible for one and not the other. It is an open question how this separation in eligibility determination will affect labor market outcomes.

Previous work on the impact of Medicaid eligibility on welfare participation has led to mixed results. In a widely cited paper, Yelowitz (1995) provides evidence from March Current Population Survey (CPS) data that increasing Medicaid income limits significantly lowered the probability of a woman with dependent children being on welfare and increased the probability of labor force participation. In recent work examining transitions into and out of welfare (Ham and Shore-Sheppard 2001), we use data from the Survey of Income and Program Participation (SIPP) to study whether the effect found by Yelowitz was due to increases in the Medicaid income limits increasing the transition rate out of welfare, reducing the transition rate into welfare, or a combination of both effects. Surprisingly, given the significance of the Yelowitz estimates, we do not find a significant effect of the Medicaid income limits on either transition rate. Considering the possibility that our results may reflect a lack of power in the data to estimate a multiple state duration model, we then look at the static relationship between Medicaid income limits and welfare participation in the SIPP. Again we do not find a significant effect of increasing the Medicaid income limits on welfare participation. To understand why the SIPP and the CPS produce different results, we re-examine the evidence from the CPS found in Yelowitz (1995). In this paper we report on this re-examination.

We find that Yelowitz's results occur in part because he imposed a strong restriction on the parameter estimates. Specifically, he constrained the Medicaid income limits and AFDC income limits to have effects that are equal in magnitude but with opposite signs. This constraint 
on the parameters is not predicted by theory and is rejected in the CPS data. When we relax this constraint we still find a significant relationship between the Medicaid income limits and welfare participation, but the coefficient on the Medicaid income limit is much smaller than the one on welfare benefits. Yelowitz also incorrectly calculated the AFDC income limits in his analysis. To be eligible for AFDC, families must pass two income tests-a "net test" that income less disregards be below a limit set by the state, and a "gross test" that income be below another stateset limit. In his analysis, Yelowitz ignores the gross test, despite the fact that it is binding on some families, particularly those with multiple children. When we calculate the AFDC income limits correctly, we cannot find a significant relationship between the Medicaid income limits and welfare or labor force participation in the CPS, independent of whether we constrain the Medicaid and AFDC income limits to have equal and opposite effects. Finally, Yelowitz used data from 1989-1992; when we extend the data set to the period 1988-1996 we continue to find no effect of Medicaid when we relax the constraint on the Medicaid and AFDC income limits or use the gross test to construct the AFDC income limit. We conclude that there is no statistically significant evidence of a relationship between welfare or labor force participation and increases in the Medicaid income limits in the CPS data.

In the next section of the paper we summarize the legislative changes in Medicaid eligibility. The third section reviews the previous literature on the link between Medicaid, welfare, and labor force participation. In section four we discuss theoretical predictions about welfare and labor force participation following the extension of Medicaid eligibility to welfareineligible individuals, and outline our empirical strategy. Our empirical results are in section five, and section six concludes. 


\section{Expansions in Medicaid Eligibility}

Historically, eligibility for Medicaid among low-income single-parent families was restricted to those whose incomes were low enough to qualify for AFDC. AFDC eligibility required that the family's income and resources be less than state-established income limits, most of which were well below the federal poverty line. This meant that few working mothers were able to qualify for AFDC and Medicaid. It also meant that if a woman were to leave welfare, she and her children would lose their Medicaid coverage. Starting in the mid-1980s, a series of federal laws uncoupled Medicaid eligibility from AFDC eligibility, expanding the population eligible for Medicaid to include poor pregnant women and children previously ineligible for AFDC. Under the expansions, Medicaid eligibility determination for children differed from AFDC eligibility determination in three fundamental ways: the child eligibility limits were linked to the federal poverty line rather than to the AFDC limits, there were no family structure requirements, and eligibility was determined at the individual, rather than family, level.

The Medicaid expansions began in 1986 and continued through the early 1990s, with effective dates and phasing-in of the legislation making the dates of actual coverage changes somewhat later. In the Omnibus Budget Reconciliation Acts (OBRAs) of 1986 and 1987, states were given the authority to raise the income thresholds for Medicaid coverage of certain groups above the AFDC level. In addition, OBRA 1987 required states to cover all children born after September 30, 1983 who met AFDC income standards, regardless of their family composition. The Medicare Catastrophic Coverage Act (MCCA) and Family Support Act (FSA), both of 1988, required states to extend Medicaid eligibility even further. The MCCA required coverage of pregnant women and infants and permitted coverage of children up to 8 years of age with family 
incomes below 75 percent of the poverty level. Coverage of eligible two-parent families where the principal earner was unemployed was mandated by the FSA. The most far-reaching expansions took place as a result of OBRA 1989 and OBRA 1990. OBRA 1989 required coverage of pregnant women and children up to age 6 with family incomes below 133 percent of the federal poverty level, and OBRA 1990 required states to cover children born after September 30, 1983 with family incomes below 100 percent of the federal poverty level. These children continue to be covered as they grow older, until they reach age 18 .

\section{Previous Literature}

As we noted in the Introduction, the question of whether breaking the link between Medicaid and cash assistance led to reduced welfare and increased labor force participation has been studied by Yelowitz (1995). He uses four years of March CPS data, from 1989 to 1992, to estimate whether the probabilities that a single mother is in the labor force or is on welfare are affected by the Medicaid expansions. Since the Medicaid expansions covered primarily children, rather than the mothers themselves (an exception is mothers who are pregnant), he uses the Medicaid income limits facing the mother's youngest child to capture the extent to which the expansions affected a particular woman. He expresses both the Medicaid income limits for the mother's youngest child and the AFDC income limits as a percentage of the federal poverty line to obtain variables MEDICAID\% and AFDC\% respectively. He sets MEDICAID\% equal to zero 
for periods when one could only obtain Medicaid through AFDC or if no child in the family is age-eligible for Medicaid given the expansions. ${ }^{1}$ Then he parameterizes the expansions as

$$
\mathrm{GAIN} \%=\max (\mathrm{MEDICAID} \%-\mathrm{AFDC} \%, 0) .
$$

MEDICAID\% depends on the age of the child, the state of residence, and the year. (The expansions were targeted towards younger children first, phased in gradually, and differed by state depending on the extent to which the state implemented optional expansions as well as the federally mandated expansions.) Non-zero levels of MEDICAID\% typically range from 75 to 185 percent of the poverty line. AFDC\%, which is the maximum income a family could earn and still receive AFDC benefits, depends on the size of the family, the age structure of the family, the state of residence, and the year. Levels of AFDC $\%$ are typically below 100 percent of the poverty line, although because of work expense and child care deductions it is possible for AFDC $\%$ to exceed 100 percent in particularly generous states.

To gain better intuition on this specification, define a variable MED* which equals AFDC $\%$ before the expansions or if no child in the family is eligible for Medicaid. It equals the Medicaid income limit applying to the youngest child divided by the poverty line if a child is age-eligible for Medicaid. (Note that MED* defines the income limit necessary for Medicaid eligibility; in the period before the expansions it simply equals the AFDC income limit.) Then GAIN\% also can be written as

$$
\text { GAIN } \%=M^{*} \text { - AFDC } \% \text {. }
$$

${ }^{1}$ By age-eligible we mean that the child would be eligible for Medicaid given his or her age if the family's income was below the Medicaid income limit for that age. 
Using this parameterization of the impact of the Medicaid expansions, Yelowitz estimates probit models of labor force participation and welfare participation. In addition to GAIN\%, he includes the number of children in the family under six years old and various characteristics of the mother including age, marital status (divorced, separated, or never married), race, education, and central city residence. He also includes dummy variables for state, year, family size, age of the youngest child, and an interaction between age of the youngest child and year. These dummies are intended to capture other factors in states or changes over time that could affect welfare and labor force participation. He also estimates models including interactions between state and year, between youngest child's age and year, and between youngest child's age and state to ensure that unobserved factors are not the source of any effect of GAIN \%. These models show a statistically significant coefficient on GAIN\% for both labor force and welfare participation in virtually all specifications, suggesting that expanding Medicaid reduced the probability of welfare participation by 1.2 percentage points and increased the probability a woman is in the labor force by 0.9 percentage points. However, from the specification of GAIN\% in (2), it can be seen that Yelowitz is assuming that i) before the expansions or if no child is age-eligible in the family, AFDC\% does not affect the probability that a woman is on welfare, and ii) if a child is age-eligible, increasing AFDC $\%$ holding GAIN\% constant does not affect the probability that a woman is on welfare. We examine these restrictions from both theoretical and empirical perspectives below.

In addition to the work by Yelowitz on the Medicaid expansions, several previous studies examine the link between public health insurance and welfare participation. These studies find mixed evidence for an impact of Medicaid on welfare participation and labor supply. Because 
Medicaid was obtained solely through participation in welfare prior to the expansions, these studies confront the question of how to identify separately the impact of Medicaid on labor supply from the impact of other programs such as AFDC and Food Stamps. While theoretically the benefits provided by Medicaid would increase the likelihood that an individual would participate in welfare and not the labor market, because Medicaid was rarely received in the absence of cash welfare payments identifying the marginal effect of Medicaid was difficult. To address this problem both Blank (1989) and Winkler (1991) calculate a state-specific value of Medicaid and include it in individual AFDC participation, labor force participation, and hours worked equations. They find generally small and usually statistically insignificant effects of the value of Medicaid. Moffitt and Wolfe (1992) develop a family-specific proxy for the value of Medicaid and include it in cross-sectional probit equations of AFDC participation and employment. They obtain estimated effects of Medicaid that are larger in magnitude than found previously, statistically significant, and of the sign predicted by theory, with more valuable Medicaid benefits leading to higher rates of AFDC participation and lower rates of labor force participation. However the value of Medicaid proxy used in their study may capture other unobserved differences between families that affect labor force and welfare participation such as tastes or the wage available to the mother. In fact, when they allow the effect of Medicaid to differ for families with low and high values of Medicaid, they find that only families with high expected medical expenditures alter their AFDC participation or employment decisions in response to Medicaid availability. Consequently, these results may not indicate what the effect of de-linking Medicaid and AFDC for the welfare population as a whole would be, unlike the methods used by other studies. 


\section{Theoretical Predictions and Basic Econometric Model}

To derive predictions about welfare and labor force participation behavior when Medicaid can be received separately from welfare, we consider the optimization problem of an individual with dependent children who: i) can collect welfare and receive Medicaid ii) can work with earnings up to the Medicaid limit and still receive Medicaid and iii) can work with earnings above the Medicaid limit and not receive Medicaid. To simplify the discussion at this stage, we ignore the following institutional features: i) a fixed amount plus a certain level of child care expenses (the disregard) can be deducted from income before welfare benefits are reduced; ii) the mother will lose her Medicaid coverage when she leaves AFDC, as may some of her children; and iii) earned income must be no higher than 1.85 times the state-set "need standard" (the gross test). We also assume that the individual has been earning income while on welfare for at least 4 months, so that any earnings (above the disregard) are effectively taxed at $100 \%$. Finally, we assume that there are no fixed costs of participation. We discuss relaxing each of these assumptions below; unless otherwise noted relaxing these assumptions does not affect our theoretical predictions. We focus on AFDC participation in what follows, but the results are easily extended to labor force participation.

Figure 1 shows the relevant budget constraint. If the consumer does not work in the labor market, she receives income $\mathrm{Y}_{\mathrm{w}}$ and Medicaid services $\mathrm{M}$ - this is point $\mathrm{C}$ in the Figure. Since we assume for now that the woman is subject to a $100 \%$ tax rate, $\mathrm{Y}_{\mathrm{w}}$ equals both the benefit level and the breakeven level. Prior to the Medicaid expansions, the family loses its Medicaid once it leaves welfare, and the overall budget constraint is ACDEH. After the Medicaid expansions the family can keep its Medicaid benefits as long as its earnings are below $\mathrm{Y}_{\mathrm{m}}$. The effective budget 
constraint is ACDFGH. Figure 1 shows the indifference curves for an individual who would not work in the absence of the Medicaid expansions, but does work (with an equilibrium at J) after the expansions. ${ }^{2}$

It is straightforward to calculate comparative static results for this individual. Since the budget constraint is not differentiable, and because the opportunity set is not compact, we use graphs to obtain these results. Figure 2 shows the change in the budget constraint when welfare benefits are raised from $Y_{w}$ to $Y_{w^{\prime}}$. The new budget constraint is AKLFGH. It is clear that this change will not induce someone to leave welfare, however it will induce some individuals to move from off welfare to on welfare, as shown in Figure 2. Thus we expect that the probability of being on welfare will be positively affected by an increase in welfare benefits.

In Figure 3 we show the effect on the budget constraint of increasing the Medicaid income limit from $Y_{m}$ to $Y_{m^{\prime}}$. The budget constraint changes from $A C D F G H$ to $A C D F^{\prime} G^{\prime} H$. This will not induce anyone not on welfare to enter welfare. However it will induce some individuals to leave welfare as shown in the Figure, and we expect that the probability of being on welfare is negatively related to the Medicaid income limit.

In Figure 4 we show the effect on the budget constraint of raising the wage from $\mathrm{w}$ to $\mathrm{w}^{\prime}$. As in Figure 1, the original budget constraint is ACDFGH, and the new budget constraint is $\mathrm{ACD}^{\prime} \mathrm{F}^{\prime} \mathrm{G}^{\prime} \mathrm{H}^{\prime}$. The change in the wage will induce some women to leave welfare but will not induce anyone to enter welfare. However, this unambiguous prediction of the wage effect is affected by our simplifications. If we were to assume that an individual had not been earning

\footnotetext{
${ }^{2}$ See Yelowitz (1995), Figures I and II.
} 
income while on welfare and thus the effective tax rate on earnings while on welfare was less than $100 \%$, the effect of the wage on welfare participation is ambiguous.

On the basis of this analysis, we write the index function describing whether someone is on welfare as a function of wages $\mathrm{w}_{\mathrm{i}}$, the Medicaid income limit as a percentage of the poverty line $y_{\mathrm{mi}}$, the level of welfare benefits as a percentage of the poverty line $\mathrm{y}_{\mathrm{wi}}$ and demographic and demand variables $\mathrm{X}_{\mathrm{i}}$. (Upper case values of $\mathrm{Y}$ represent dollar amounts while lower case values of y represent dollar amounts divided by the poverty line. $)^{3}$ We have $^{4}$

$$
I_{i}^{*}=\gamma_{0}+\gamma_{1} y_{m i}+\gamma_{2} y_{w i}+\gamma_{3} w_{i}+\gamma_{4} X_{i}+e_{i} .
$$

Since the wage is unobserved, we assume that it depends on variables $Z_{i}$

$$
w_{i}=\beta Z_{i}+u_{i} .
$$

We assume that $Z_{\mathrm{i}}$ does not contain the Medicaid income limit $Y_{\mathrm{mi}}$ and the level of welfare benefits $Y_{\text {wi }}$. Substituting (4) into (3) and letting $X_{i}^{*}$ denote the unique elements of $Z_{i}$ and $X_{i}$, the index function becomes

$$
I_{i}^{*}=\mu_{0}+\gamma_{1} y_{m i}+\gamma_{2} y_{w i}+\mu_{1} X_{i}^{*}+\varepsilon_{i} .
$$

We note that Yelowitz estimates a restricted version of (5) which constrains $\mathrm{y}_{\mathrm{mi}}$ and $\mathrm{y}_{\mathrm{wi}}$ to have coefficients that are equal in absolute value but opposite in sign

$$
\gamma_{1}=-\gamma_{2}
$$

${ }^{3}$ One can interpret dividing by the poverty line as deflating by a price index for low income families.

${ }^{4}$ For a more structural approach to the issue of participating in income maintenance programs, see Ashenfelter (1983). 
The constraint (6) has two implications. First, if the youngest child is age-eligible for Medicaid, welfare benefits do not affect the probability of being on welfare conditional on the value of Gain $\left(y_{m i}-y_{w i}\right)$ staying constant. Second, if no child is age-eligible, then increasing welfare benefits will not induce anyone to enter welfare. We now investigate whether these implications are consistent with our theoretical model.

As the counterexample in Figure 5 shows, the first restriction is not, in general, implied by the theoretical model. Here we show that an equal increase in $Y_{m i}$ and $Y_{w i}$ affects behavior and thus the Yelowitz restriction does not hold. In this example the individual originally has a tangency at $\mathrm{J}$ on the segment $\mathrm{DF}$ of the budget constraint, where the overall budget constraint is ACDFGH. When the levels of $Y_{\mathrm{mi}}$ and $\mathrm{Y}_{\mathrm{wi}}$ are increased by the same amount, the budget constraint becomes $A K D^{\prime} F^{\prime} G^{\prime} H$. For a sufficiently high increase in $Y_{m i}$ and $Y_{w i}$, the individual moves to point $\mathrm{K}$ where she does not work. The intuition is straightforward: since the individual originally has a tangency on the segment DF, increasing the Medicaid limit does not benefit her. On the other hand, a sufficient increase in $\mathrm{Y}_{\mathrm{wi}}$, such as that shown in the Figure, allows her to reach a higher indifference curve by entering welfare.

It is straightforward to show that the second implication does not hold either. If no child is age-eligible for Medicaid, we have the textbook AFDC case. It is well known that increasing AFDC benefits in this case will encourage some individuals to enter welfare, but will not encourage anyone to leave welfare. Thus both of the implications of Yelowitz's restriction (6) are inconsistent with the theoretical predictions of our model. 


\section{$\underline{\text { Allowing for Important Institutional Features }}$}

The actual budget constraint is somewhat more complicated than this stylized model indicates. First, individuals face fixed costs of participation in terms of day care expenses. Second, they are allowed to deduct a disregard equal to a constant dollar amount, a, plus actual day care expenses (up to a per child limit) D before their earnings are taxed at $100 \%$. In this case maximum feasible earnings become $\mathrm{Y}_{\mathrm{wi}}{ }^{*}=\mathrm{Y}_{\mathrm{wi}}+\mathrm{a}+\mathrm{D}$, and we use this variable (divided by the poverty line) in our index function (3) instead of $\mathrm{y}_{\text {wi. }}$

Third, in the first four months of earnings while on welfare, participants are permitted to disregard an additional fraction $\mathrm{k}$ of earnings before the tax rate is applied. Countable income (the income subtracted from the payment standard to determine the benefit) is thus (1-k) times an individual's earnings less other disregards, and the maximum feasible income becomes $\mathrm{Y}_{\mathrm{wi}}{ }^{* *}$, which equals $\mathrm{Y}_{\mathrm{wi}} /(1-\mathrm{k})+\mathrm{a}+\mathrm{D}$ before October 1989 and $\left(\mathrm{Y}_{\mathrm{wi}}+\mathrm{a}+\mathrm{D}\right) /(1-\mathrm{k})$ after October $1989 .^{5}$ If we assume, as did Yelowitz, that the first four months' maximum feasible earnings is the relevant amount, then we would use $\mathrm{Y}_{\mathrm{wi}}{ }^{* *}$ (divided by the poverty line) in the index function (5).

Fourth, as noted above, the mother, and perhaps some of her children, will lose her Medicaid coverage when she leaves AFDC. In terms of Figure 1, this will cause the line segment DF to shift down by the amount that the mother values the portion of Medicaid coverage only available through AFDC. This shift creates a notch at D.

Finally, there is also a gross test, which requires that maximum feasible earnings not exceed 1.85 times the state-determined need standard (NS). Maximum feasible earnings after 4

${ }^{5}$ The Family Support Act of 1988 changed the calculation of benefits so that the income not subject to the "tax" is calculated before applying the disregards, increasing the possible benefit level. 
months of earnings while on welfare are thus $\mathrm{Y}_{\mathrm{wi}}{ }^{* * *}=\operatorname{minimum}\left(1.85 \mathrm{NS}, \mathrm{Y}_{\mathrm{wi}}{ }^{*}\right)$. In the first four months of working while on welfare maximum feasible earnings become

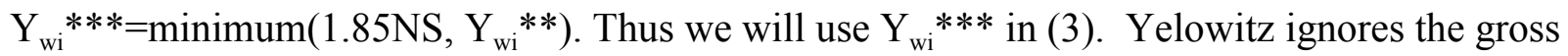
test in calculating maximum feasible income which is inappropriate. It is straightforward to show that none of these modifications affect the theoretical predictions discussed above.

\section{Measuring the Medicaid Expansions' Effect on Welfare and Labor Force Participation}

Data

Following the previous literature, we use several years of the March Current Population Survey-from 1988 to 1996-to examine the effect of the expansions. The March CPS surveys many households, providing the largest available data set of single mothers containing information on welfare and labor force participation, demographics, and family structure. To ensure comparability between our results and those of Yelowitz, we use the same sample selection criteria as he does-single mothers between the ages of 18 and 55 with at least one child under 15 present. This results in a sample of 16,022 single mothers for the years 1989 to 1992 (the years used by Yelowitz) and 36,628 single mothers for the entire 1988 to 1996 sample. ${ }^{6}$ Again following Yelowitz, we impute Medicaid eligibility criteria to the mother's youngest child using year of birth (calculated from the reported age as of March of the survey year) and a

${ }^{6}$ Throughout the paper, years refer to the year in which the survey was conducted. Our sample size differs slightly from that of Yelowitz (smaller by 40 observations) because we lack information on state AFDC standards for families with more than nine members. We eliminate these families from our sample rather than assigning them a value of GAIN \% equal to 0 , as Yelowitz did. Note that since we treat family size as exogenous, we do not create selection bias by deleting these families. 
randomly assigned month of birth. ${ }^{7}$ As noted above, the variable MEDICAID\% is the imputed Medicaid income threshold for the mother's youngest child as a percent of the poverty line. Using state AFDC need and payment standards we impute AFDC breakeven levels under Yelowitz's assumption that the family takes the full childcare disregard for all children under 18. We again follow Yelowitz in assuming that individuals make their decisions about welfare based on the first four months of earnings on welfare. ${ }^{8}$ This variable is divided by the poverty line as well, yielding AFDC\%. MED* equals AFDC\% if the Medicaid expansions are not in effect or the child is not age-eligible; otherwise it equals MEDICAID \%. The variable GAIN\% used by Yelowitz is thus GAIN\%=MED*-AFDC $\%$.

Sample statistics broken down by time period, i.e. 1989-1992 and 1988-1996, are presented in Table 1. In the 1989-1992 sample the mean of GAIN\% is only approximately 4 percent of the poverty line. It is very small because so many observations are zero, which occurs when the AFDC income limit exceeds the Medicaid income limit. This is relatively common when the gross test is not used. In fact, the mean value of the AFDC income limit exceeds the poverty line, even though no state has a need standard as high as the poverty line. This is due to the assumption of the full child care disregard. Using the gross test reduces the mean value of the AFDC limit to 106.11 percent of poverty.

${ }^{7}$ While the random assignment of birth month creates measurement error in the Medicaid eligibility limit, testing alternative methods of assignment shows that they have little to no effect on estimated Medicaid eligibility levels (Shore-Sheppard 1996).

${ }^{8} \mathrm{We}$ also considered various alternative assumptions for the childcare disregard, and the possibility that the AFDC income limits should be based on those for months 5 and following of working while on welfare. None of these changes affected the estimated effect of the Medicaid expansions. 
The results for the whole 1988-1996 sample are broadly similar. Since there are later years of data in the whole sample, the mean Medicaid income limit is higher-82 percent of the poverty line instead of 57 percent. (It is 135 percent instead of 126 percent when only mothers whose youngest children are age-eligible for Medicaid are included.) The AFDC limits are lower in the whole sample than the 1989-1992 sample, suggesting a trend towards reduced real AFDC benefits. The fact that AFDC limits may fall while the Medicaid income limit rises shows the importance of allowing AFDC and Medicaid to have separate effects, since using GAIN\% alone will attribute the effect of any decreases in AFDC generosity on welfare participation to the Medicaid expansions.

\section{$\underline{\text { Results }}$}

The results from our replication of Yelowitz's work using the same data set, the 19891992 March Current Population Surveys, are presented in Tables 2 through 5. Tables 2 and 3 report the basic results for probit models of labor force and AFDC participation, respectively. ${ }^{9}$ The first two columns of each table show Yelowitz's original results and our attempt to replicate them. We are unable to replicate the results exactly, but our results are quite close to his. ${ }^{10}$ These results indicate that the variable GAIN\%, which is the difference between the Medicaid and AFDC income limits (MED* and AFDC\%, respectively), has a positive and significant effect on labor force participation and a negative and significant effect on AFDC participation. In addition, the control variables enter generally as would be expected. Single mothers with

${ }^{9}$ These specifications correspond to Table IV in Yelowitz (1995). In all specifications, the Medicaid and AFDC variables are scaled to be fractions, rather than percentages.

${ }^{10}$ At least part of the explanation for the inexact replication is that, as noted earlier, our treatment of families with more than nine members differs. 
more young children are less likely to participate in the labor force and more likely to participate in welfare, as are mothers who are black, living in a central city, or never married.

We show the effect of including the gross test in the calculation of the AFDC maximum income level in column 3 of the tables. While the coefficients on the demographic variables are essentially unchanged, the magnitude of the estimated effect of GAIN\% is reduced substantially in both tables, and the effect is no longer statistically significant. Including the gross test reduces the imputed AFDC maximum income level because the gross test is binding when income after disregards is relatively high. This tends to occur when there are many children in the family, since the child care disregard is the primary reason that income after disregards may be high. The fact that including the gross test in the AFDC calculation reduces the magnitude of the effect of GAIN\% suggests that AFDC income levels are playing an important role in determining the effect of GAIN $\%$.

We consider this hypothesis in columns 4 and 5 in each table by allowing AFDC maximum income levels and Medicaid maximum income levels (AFDC\% and MED* respectively) to have separate effects. We then test the restriction implied by the use of GAIN\% that the effects are equal and of opposite sign. For comparison column 4 shows the results without including the gross test, while column 5 gives the (more appropriate) results with the gross test included. In both columns in Tables 2 and 3 the estimated effect of AFDC is substantially larger in absolute value than the estimated Medicaid effect, and we can easily reject the null hypothesis that the coefficients have equal but opposite-signed effects. While the estimated Medicaid effect is marginally statistically significant when the gross test is not included, it becomes much smaller and insignificant when the gross test is included. The AFDC 
effect also becomes smaller, although it remains statistically significant. These results suggest that interpreting the coefficient on GAIN\% as an effect of expanding Medicaid is incorrect; much of the variation in GAIN\% that yields increased labor force participation and reduced welfare participation appears to be due to variation in the AFDC income limits rather than in the Medicaid income limits. The marginal effects, which are calculated as the derivative of the normal cumulative density evaluated at the means of the data, are -0.11 for labor force participation and 0.15 for AFDC participation. The magnitude of these effects indicates that a one percentage-point increase in the AFDC income limit as a percent of the poverty line yields a decrease of 0.0011 in the probability of labor force participation at mean values. It would also cause a 0.0015 increase in the probability of AFDC participation at the mean values. For comparison, the predicted probability of labor force participation evaluated at the means is 0.73 , and the predicted probability of AFDC participation at the means is $0.28 .{ }^{11}$

Yelowitz found that including state-time interactions to control for the possibility of statespecific trends increased the absolute value of the coefficient on GAIN\% in both the labor force and AFDC participation equations. We do not find this to be the case when we attempt to replicate his result (columns 2 and 3 of the first panel of Tables 4 and 5 ). ${ }^{12}$ However when we allow AFDC and Medicaid to have unrestricted effects, we find that the coefficients on AFDC \% in both the labor force and AFDC participation equations are larger in absolute value than when the interactions are not included, while the Medicaid coefficients continue to be insignificantly

\footnotetext{
${ }^{11}$ We use column 5 in Tables 2 and 3 for these calculations.

${ }^{12}$ These specifications correspond to Tables IV and VI in Yelowitz (1995).
} 
different from 0 (columns 4 and 5 of the first panel). Again we can reject the null hypothesis that the Medicaid and AFDC coefficients are equal in magnitude but opposite in sign.

The bottom two panels of Tables 4 and 5 show the results for ever married and never married women separately. When GAIN\% is used, only ever married women show statistically significant effects, which Yelowitz attributed to a greater responsiveness to Medicaid expansions among ever married women. When AFDC and Medicaid are allowed to have separate effects, however, both groups of women have AFDC coefficients that are similar in magnitude and statistical significance (column 5 of the bottom two panels of Tables 4 and 5). The Medicaid coefficients are also similar for the two groups in the AFDC participation equation and are again statistically insignificant. The only sign of a possible Medicaid effect is in the labor force participation equation for ever married women (column 5 of the second panel in Table 4), although the effect is so imprecisely estimated that it is not statistically distinguishable from 0 .

Tables 6 through 9 repeat the same analysis as in Tables 2 through 5 using the whole sample covering 1988-1996. The results are broadly the same as when we use only data from the period 1989-1992 (i.e. the years used by Yelowitz). The coefficient on GAIN\% is smaller in the whole sample, and again including the gross test reduces the estimated effect substantially. Allowing the AFDC and Medicaid effects to differ demonstrates the relative importance of the AFDC income limits. We reject the null hypothesis that Medicaid and AFDC income limits have equal but opposite-signed effects in all cases, indicating that the results in the last column are most consistent with the data.

Not surprisingly, the addition of five years of data cuts the standard errors roughly in half. Nevertheless, none of the Medicaid coefficients are statistically different from 0 when the gross 
test is used. (Again the Medicaid coefficient in the labor force participation equation for ever married women comes closest to statistical significance.) The AFDC income limits also have coefficients that are very similar in magnitude to those in the original sample (the marginal effects are -0.13 for labor force participation, as compared to -0.11 , and 0.18 for AFDC participation, as compared to 0.15$)$.

The coefficients on the control variables tend to be smaller in the whole sample.

However, the coefficients on number of children younger than 6 are larger. The absolute value of the education coefficients is larger in both the labor force and AFDC participation equations, although the derivatives of the index function at 12 years of schooling are quite similar in both samples. Finally, the coefficients on mother's age in the AFDC participation equations are also larger, but the derivatives at 30 years of age are again quite similar in both samples.

\section{Conclusions}

There has been strong interest in factors that help single-headed families leave cash assistance for many years, and the replacement of AFDC by TANF has accentuated this interest. Based on economic theory and the empirical work of Yelowitz (1995), it appeared that the Medicaid expansions would decrease participation in cash assistance by breaking the link between AFDC and Medicaid for children. In this paper we re-examine the evidence from the CPS found in Yelowitz (1995).

We conclude that there is no significant evidence of a negative relationship between welfare participation and increases in the Medicaid income limits in the CPS data. Nor is there evidence that the Medicaid expansions increased labor force participation. We find that 
Yelowitz's results were the result of two factors. First, he imposed a strong restriction on the parameter estimates that is not predicted by theory and is rejected in the CPS data. Second, he incorrectly calculated the AFDC breakeven income by ignoring the gross test. Once these problems are addressed, the Medicaid income limits have no significant effect on AFDC participation. The AFDC income limits, however, are significantly related to welfare and labor force participation in both the 1989-1992 and 1988-1996 samples.

The importance of the AFDC income limits is not surprising in light of the theoretical results above. However the lack of a Medicaid effect is somewhat surprising, as the theory shows that it is plausible for a woman to respond to the Medicaid expansions by moving from welfare to work. One possible explanation for the lack of an effect detectable in the data is suggested by the theory. As noted above, Figure 1 will overstate the value of the Medicaid expansions to the family. AFDC provides cash assistance and Medicaid for the woman herself as well as all of her children, but the woman and any older children would not be eligible for coverage under the expansions, implying that the value of Medicaid coverage under the expansions may be small. In that case, the number of women with a tangency at a point such as $\mathrm{J}$ in Figure 1 may be too small to detect in the data. ${ }^{13}$

${ }^{13}$ One might argue that the Medicaid coefficient is being biased in absolute value because we omit wages in the equation and wages for low income workers are falling over this period while the Medicaid income limits are rising. However, our most general specification contains state dummies interacted with time dummies, which will capture much of the movement in wages. 


\section{References}

Ashenfelter, Orley. 1983. "Determining Participation in Income-Tested Social Programs." Journal of the American Statistical Association 78:383, pp. 517-525.

Blank, Rebecca M. 1989. "The Effect of Medical Need and Medicaid on AFDC Participation." Journal of Human Resources 24:1, pp. 54-87.

. 2001. "What Causes Public Assistance Caseloads to Grow?" Journal of Human Resources 36(1), pp. 85-118.

Cutler, David and Jonathan Gruber. 1996. "Does Public Insurance Crowd Out Private Insurance?" Quarterly Journal of Economics 111:2, pp. 391-430.

Ham, John C. and Lara D. Shore-Sheppard. 2001. "The Impact of Public Health Insurance on Employment Transitions.” Mimeograph, January.

Meyer, Bruce D. and Dan T. Rosenbaum. 2001. "Welfare, the Earned Income Tax Credit, and the Employment of Single Mothers." Quarterly Journal of Economics 116:3, pp. 1063-1114.

Moffitt, Robert and Barbara Wolfe. 1992. "The Effect of the Medicaid Program on Welfare Participation and Labor Supply." Review of Economics and Statistics 74:4, 1992, pp. 615-626.

National Governors' Association Center for Policy Research. 1998-1996. "State Coverage of Pregnant Women and Children." Washington, DC: National Governors' Association. Unpublished reports.

Shore-Sheppard, Lara. 1996. "Medicaid and Health Insurance for Children: Essays in Empirical Economics.” Dissertation, Princeton University.

U.S. House of Representatives Committee on Ways and Means. 1987-2000. Green Book:

Background Material and Data on Programs Within the Jurisdiction of the Committee on Ways and Means. Washington, DC: U.S. Government Printing Office.

Winkler, Anne. 1991. "The Incentive Effects of Medicaid on Women's Labor Supply," Journal of Human Resources 26, pp. 308-337.

Yelowitz, Aaron. 1995. "The Medicaid Notch, Labor Supply, and Welfare Participation: Evidence from Eligibility Expansions." Quarterly Journal of Economics 110:4, pp. 909940. 
Table 1: Sample Statistics

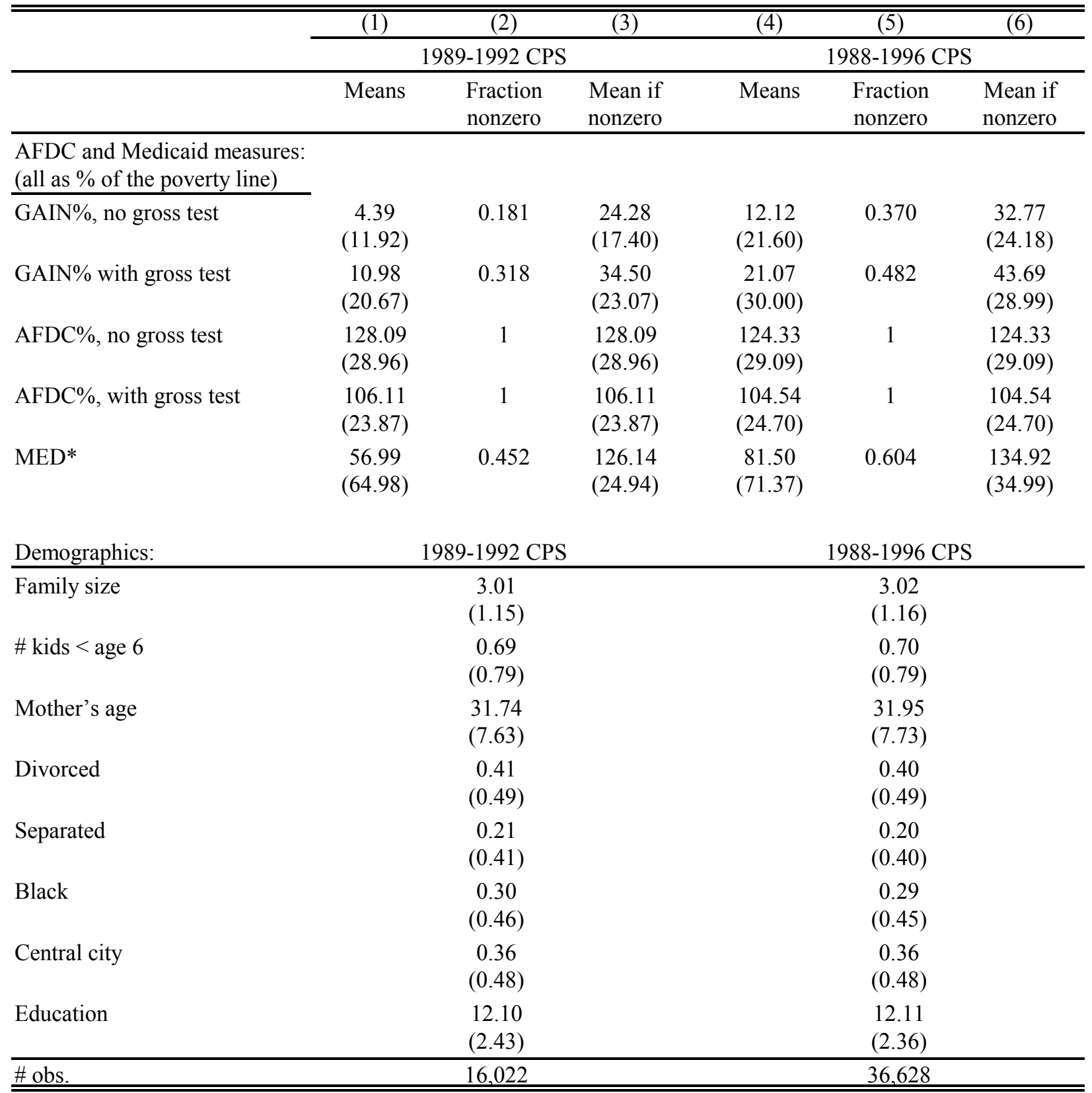

Notes: Standard deviations in parentheses. Sample includes single mothers ages 18-55 with a child under 15 from the 1989-1992 or 1988-1996 March Current Population Surveys. GAIN \% $=\max ($ MEDICAID $\%-$ AFDC $\%, 0)=$ MED*-AFDC\%. See text for descriptions of how MEDICAID\%, MED* and AFDC\% were constructed.. In the estimates that follow, the Medicaid and AFDC variables are scaled to be fractions, rather than percentages. 
Table 2: Probit Models of Labor Force Participation, 1989-1992 March Current Population Surveys

\begin{tabular}{|c|c|c|c|c|c|}
\hline & (1) & (2) & (3) & $(4)$ & $(5)$ \\
\hline & $\begin{array}{l}\text { Yelowitz Table } \\
\text { IV, col. } 1\end{array}$ & Replication & $\begin{array}{l}\text { Incorporating } \\
\text { gross test }\end{array}$ & $\begin{array}{l}\text { Allow diff. effects for } \\
\text { AFDC and Medicaid }\end{array}$ & $\begin{array}{c}\text { Diff. effects } \\
\text { incorporating gross } \\
\text { test }\end{array}$ \\
\hline GAIN \% & $\begin{array}{c}0.3840 \\
(0.1509)\end{array}$ & $\begin{array}{l}0.3927 \\
(0.1209) \\
{[0.1309]}\end{array}$ & $\begin{array}{c}0.1054 \\
(0.0884) \\
{[0.0350]}\end{array}$ & & \\
\hline MED* & & & & $\begin{array}{c}0.2039 \\
(0.1231) \\
{[0.0679]}\end{array}$ & $\begin{array}{c}0.0579 \\
(0.0910) \\
{[0.0193]}\end{array}$ \\
\hline AFDC $\%$ & & & & $\begin{array}{l}-1.3291 \\
(0.1598) \\
{[-0.4427]}\end{array}$ & $\begin{array}{l}-0.3215 \\
(0.1320) \\
{[-0.1072]}\end{array}$ \\
\hline$\#$ kids $<$ age 6 & $\begin{array}{l}-0.1382 \\
(0.0286)\end{array}$ & $\begin{array}{l}-0.1484 \\
(0.0294)\end{array}$ & $\begin{array}{l}-0.1602 \\
(0.0291)\end{array}$ & $\begin{array}{l}-0.1031 \\
(0.0299)\end{array}$ & $\begin{array}{l}-0.1566 \\
(0.0292)\end{array}$ \\
\hline Mother's age & $\begin{array}{c}0.0597 \\
(0.0121)\end{array}$ & $\begin{array}{c}0.0615 \\
(0.0117)\end{array}$ & $\begin{array}{c}0.0592 \\
(0.0117)\end{array}$ & $\begin{array}{c}0.0796 \\
(0.0119)\end{array}$ & $\begin{array}{c}0.0609 \\
(0.0117)\end{array}$ \\
\hline $\mathrm{Age}^{2} / 100$ & $\begin{array}{l}-0.0836 \\
(0.0177)\end{array}$ & $\begin{array}{l}-0.0845 \\
(0.0168)\end{array}$ & $\begin{array}{l}-0.0812 \\
(0.0168)\end{array}$ & $\begin{array}{l}-0.1139 \\
(0.0172)\end{array}$ & $\begin{array}{l}-0.0840 \\
(0.0169)\end{array}$ \\
\hline Divorced & $\begin{array}{c}0.3863 \\
(0.0314)\end{array}$ & $\begin{array}{c}0.3712 \\
(0.0314)\end{array}$ & $\begin{array}{c}0.3713 \\
(0.0314)\end{array}$ & $\begin{array}{c}0.3757 \\
(0.0315)\end{array}$ & $\begin{array}{c}0.3712 \\
(0.0314)\end{array}$ \\
\hline Separated & $\begin{array}{c}0.1742 \\
(0.0322)\end{array}$ & $\begin{array}{c}0.1637 \\
(0.0324)\end{array}$ & $\begin{array}{c}0.1641 \\
(0.0324)\end{array}$ & $\begin{array}{c}0.1750 \\
(0.0325)\end{array}$ & $\begin{array}{c}0.1640 \\
(0.0324)\end{array}$ \\
\hline Black & $\begin{array}{l}-0.0713 \\
(0.0301)\end{array}$ & $\begin{array}{l}-0.0707 \\
(0.0302)\end{array}$ & $\begin{array}{l}-0.0704 \\
(0.0301)\end{array}$ & $\begin{array}{l}-0.0707 \\
(0.0302)\end{array}$ & $\begin{array}{l}-0.0688 \\
(0.0302)\end{array}$ \\
\hline Central city & $\begin{array}{l}-0.2267 \\
(0.0271)\end{array}$ & $\begin{array}{l}-0.2155 \\
(0.0271)\end{array}$ & $\begin{array}{l}-0.2156 \\
(0.0271)\end{array}$ & $\begin{array}{l}-0.2201 \\
(0.0272)\end{array}$ & $\begin{array}{l}-0.2163 \\
(0.0271)\end{array}$ \\
\hline Educ. & $\begin{array}{l}-0.0483 \\
(0.0216)\end{array}$ & $\begin{array}{l}-0.0480 \\
(0.0215)\end{array}$ & $\begin{array}{l}-0.0487 \\
(0.0215)\end{array}$ & $\begin{array}{l}-0.0459 \\
(0.0215)\end{array}$ & $\begin{array}{l}-0.0478 \\
(0.0215)\end{array}$ \\
\hline Educ. $^{2}$ & $\begin{array}{c}0.0086 \\
(0.0010)\end{array}$ & $\begin{array}{c}0.0087 \\
(0.0010)\end{array}$ & $\begin{array}{c}0.0088 \\
(0.0010)\end{array}$ & $\begin{array}{c}0.0086 \\
(0.0010)\end{array}$ & $\begin{array}{c}0.0088 \\
(0.0010)\end{array}$ \\
\hline $\log -\mathrm{L}$ & -8196 & -8186 & -8191 & -8145 & -8188 \\
\hline \# obs. & 16,062 & 16,022 & 16,022 & 16,022 & 16,022 \\
\hline $\begin{array}{l}\chi^{2} \text { test } \\
\text { (p-value) }\end{array}$ & & & & $\begin{array}{c}81.97 \\
(0.000)\end{array}$ & $\begin{array}{c}4.87 \\
(0.0274)\end{array}$ \\
\hline
\end{tabular}

Notes: Standard errors in parentheses (except where noted), marginal effects at the means in brackets. Sample includes single mothers ages 18-55 with a child under 15 from the 1989-1992 March Current Population Surveys. GAIN $\%=\max ($ MEDICAID $\%-$ AFDC $\%, 0)=$ MED*-AFDC $\%$. See text for descriptions of how MEDICAID $\%$, MED* and AFDC\% were constructed. Regressions also include dummies for state, year, family size, age of the youngest child, and age of the youngest child interacted with year. The $\chi^{2}$ test is of the hypothesis that the coefficients on MED* and AFDC \% have equal and opposite signs, the restriction implicit in the use of GAIN \%. 
Table 3: Probit Models of AFDC Participation, 1989-1992 March Current Population Surveys

\begin{tabular}{|c|c|c|c|c|c|}
\hline & $(1)$ & (2) & (3) & (4) & (5) \\
\hline & $\begin{array}{l}\text { Yelowitz Table } \\
\text { IV, col. } 3\end{array}$ & Replication & $\begin{array}{l}\text { Incorporating } \\
\text { gross test }\end{array}$ & $\begin{array}{l}\text { Allow diff. effects for } \\
\text { AFDC and Medicaid }\end{array}$ & $\begin{array}{c}\text { Diff. effects } \\
\text { incorporating gross } \\
\text { test }\end{array}$ \\
\hline GAIN \% & $\begin{array}{l}-0.5188 \\
(0.1544)\end{array}$ & $\begin{array}{l}-0.5639 \\
(0.1244) \\
{[-0.1915]}\end{array}$ & $\begin{array}{l}-0.1174 \\
(0.0891) \\
{[-0.0400]}\end{array}$ & & \\
\hline MED* & & & & $\begin{array}{l}-0.3472 \\
(0.1265) \\
{[-0.1178]}\end{array}$ & $\begin{array}{l}-0.0459 \\
(0.0916) \\
{[-0.0156]}\end{array}$ \\
\hline AFDC $\%$ & & & & $\begin{array}{l}1.6267 \\
(0.1625) \\
{[0.5520]}\end{array}$ & $\begin{array}{c}0.4463 \\
(0.1328) \\
{[0.1515]}\end{array}$ \\
\hline$\#$ kids $<$ age 6 & $\begin{array}{c}0.1802 \\
(0.0290)\end{array}$ & $\begin{array}{c}0.1927 \\
(0.0298)\end{array}$ & $\begin{array}{c}0.2092 \\
(0.0296)\end{array}$ & $\begin{array}{c}0.1433 \\
(0.0303)\end{array}$ & $\begin{array}{c}0.2039 \\
(0.0297)\end{array}$ \\
\hline Mother's age & $\begin{array}{l}-0.0007 \\
(0.0124)\end{array}$ & $\begin{array}{l}-0.0037 \\
(0.0120)\end{array}$ & $\begin{array}{l}0.00002 \\
(0.0119)\end{array}$ & $\begin{array}{l}-0.0237 \\
(0.0121)\end{array}$ & $\begin{array}{l}-0.0027 \\
(0.0120)\end{array}$ \\
\hline $\mathrm{Age}^{2} / 100$ & $\begin{array}{l}-0.0256 \\
(0.0184)\end{array}$ & $\begin{array}{l}-0.0205 \\
(0.0174)\end{array}$ & $\begin{array}{l}-0.0256 \\
(0.0173)\end{array}$ & $\begin{array}{c}0.0121 \\
(0.0177)\end{array}$ & $\begin{array}{l}-0.0212 \\
(0.0174)\end{array}$ \\
\hline Divorced & $\begin{array}{l}-0.3528 \\
(0.0310)\end{array}$ & $\begin{array}{l}-0.3515 \\
(0.0311)\end{array}$ & $\begin{array}{l}-0.3517 \\
(0.0311)\end{array}$ & $\begin{array}{l}-0.3569 \\
(0.0312)\end{array}$ & $\begin{array}{l}-0.3518 \\
(0.0311)\end{array}$ \\
\hline Separated & $\begin{array}{l}-0.2358 \\
(0.0323)\end{array}$ & $\begin{array}{l}-0.2282 \\
(0.0325)\end{array}$ & $\begin{array}{l}-0.2288 \\
(0.0324)\end{array}$ & $\begin{array}{l}-0.2424 \\
(0.0326)\end{array}$ & $\begin{array}{l}-0.2290 \\
(0.0325)\end{array}$ \\
\hline Black & $\begin{array}{c}0.2168 \\
(0.0301)\end{array}$ & $\begin{array}{c}0.2138 \\
(0.0301)\end{array}$ & $\begin{array}{c}0.2137 \\
(0.0301)\end{array}$ & $\begin{array}{c}0.2165 \\
(0.0302)\end{array}$ & $\begin{array}{c}0.2115 \\
(0.0301)\end{array}$ \\
\hline Central city & $\begin{array}{c}0.1889 \\
(0.0271)\end{array}$ & $\begin{array}{c}0.1901 \\
(0.0271)\end{array}$ & $\begin{array}{c}0.1896 \\
(0.0271)\end{array}$ & $\begin{array}{c}0.1956 \\
(0.0272)\end{array}$ & $\begin{array}{c}0.1905 \\
(0.0271)\end{array}$ \\
\hline Educ. & $\begin{array}{c}0.1341 \\
(0.0217)\end{array}$ & $\begin{array}{c}0.1346 \\
(0.0217)\end{array}$ & $\begin{array}{c}0.1355 \\
(0.0217)\end{array}$ & $\begin{array}{c}0.1330 \\
(0.0217)\end{array}$ & $\begin{array}{c}0.1343 \\
(0.0217)\end{array}$ \\
\hline Educ. $^{2}$ & $\begin{array}{l}-0.0121 \\
(0.0010)\end{array}$ & $\begin{array}{l}-0.0122 \\
(0.0010)\end{array}$ & $\begin{array}{l}-0.0123 \\
(0.0010)\end{array}$ & $\begin{array}{l}-0.0121 \\
(0.0010)\end{array}$ & $\begin{array}{l}-0.0122 \\
(0.0010)\end{array}$ \\
\hline $\log -\mathrm{L}$ & -8311 & -8296 & -8305 & -8242 & -8300 \\
\hline \# obs. & 16,062 & 16,022 & 16,022 & 16,022 & 16,022 \\
\hline $\begin{array}{l}\chi^{2} \text { test } \\
\text { (p-value) }\end{array}$ & & & & $\begin{array}{c}105.83 \\
(0.0000)\end{array}$ & $\begin{array}{c}11.20 \\
(0.0008)\end{array}$ \\
\hline
\end{tabular}

Notes: Standard errors in parentheses (except where noted), marginal effects at the means in brackets. Sample includes single mothers ages 18-55 with a child under 15 from the 1989-1992 March Current Population Surveys. GAIN $\%=\max ($ MEDICAID $\%-$ AFDC $\%, 0)=$ MED*-AFDC $\%$. See text for descriptions of how MEDICAID $\%$, MED* and AFDC\% were constructed. Regressions also include dummies for state, year, family size, age of the youngest child, and age of the youngest child interacted with year. The $\chi^{2}$ test is of the hypothesis that the coefficients on MED* and AFDC \% have equal and opposite signs, the restriction implicit in the use of GAIN \%. 
Table 4: Labor Force Participation Models with State-Time Interactions, 1989-1992 March Current Population Surveys

\begin{tabular}{|c|c|c|c|c|c|}
\hline & $(1)$ & (2) & $(3)$ & 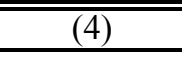 & $(5)$ \\
\hline Labor force participation: & Yelowitz results & Replication & $\begin{array}{c}\text { Incorporating } \\
\text { gross test }\end{array}$ & $\begin{array}{l}\text { Allow diff. } \\
\text { effects for } \\
\text { AFDC and } \\
\text { Medicaid }\end{array}$ & $\begin{array}{c}\text { Diff. effects } \\
\text { incorporating } \\
\text { gross test }\end{array}$ \\
\hline \multicolumn{6}{|l|}{ All women: } \\
\hline GAIN \% & $\begin{array}{c}0.4731 \\
(0.1679)\end{array}$ & $\begin{array}{c}0.3597 \\
(0.1287) \\
{[0.1195]}\end{array}$ & $\begin{array}{c}0.0927 \\
(0.0982) \\
{[0.0308]}\end{array}$ & & \\
\hline MED* & & & & $\begin{array}{c}0.0744 \\
(0.1323) \\
{[0.0247]}\end{array}$ & $\begin{array}{c}-0.0169 \\
(0.1012) \\
{[-0.0056]}\end{array}$ \\
\hline AFDC $\%$ & & & & $\begin{array}{c}-1.4928 \\
(0.1702) \\
{[-0.4954]}\end{array}$ & $\begin{array}{c}-0.7229 \\
(0.1692) \\
{[-0.2400]}\end{array}$ \\
\hline $\begin{array}{l}\chi^{2} \text { test } \\
\text { (p-value) }\end{array}$ & & & & $\begin{array}{c}106.25 \\
(0.0000)\end{array}$ & $\begin{array}{c}21.02 \\
(0.0000)\end{array}$ \\
\hline \multicolumn{6}{|l|}{ Ever married women: } \\
\hline GAIN \% & $\begin{array}{c}1.0204 \\
(0.2479)\end{array}$ & $\begin{array}{c}0.6842 \\
(0.2070) \\
{[0.1861]}\end{array}$ & $\begin{array}{c}0.2845 \\
(0.1508) \\
{[0.0774]}\end{array}$ & & \\
\hline MED* & & & & $\begin{array}{c}0.3591 \\
(0.2128) \\
{[0.0974]}\end{array}$ & $\begin{array}{c}0.1861 \\
(0.1553) \\
{[0.0506]}\end{array}$ \\
\hline AFDC $\%$ & & & & $\begin{array}{c}-1.6386 \\
(0.2461) \\
{[-0.4445]}\end{array}$ & $\begin{array}{c}-0.7520 \\
(0.2318) \\
{[-0.2045]}\end{array}$ \\
\hline $\begin{array}{l}\chi^{2} \text { test } \\
\text { (p-value) }\end{array}$ & & & & $\begin{array}{c}53.99 \\
(0.0000)\end{array}$ & $\begin{array}{c}7.09 \\
(0.0077)\end{array}$ \\
\hline \multicolumn{6}{|l|}{ Never married women: } \\
\hline GAIN \% & $\begin{array}{l}-0.0239 \\
(0.2568)\end{array}$ & $\begin{array}{c}0.1642 \\
(0.1774) \\
{[0.0641]}\end{array}$ & $\begin{array}{c}-0.0567 \\
(0.1407) \\
{[-0.0222]}\end{array}$ & & \\
\hline MED* & & & & $\begin{array}{c}-0.1433 \\
(0.1831) \\
{[-0.0564]}\end{array}$ & $\begin{array}{c}-0.1852 \\
(0.1456) \\
{[-0.0723]}\end{array}$ \\
\hline AFDC $\%$ & & & & $\begin{array}{c}-1.5911 \\
(0.2665) \\
{[-0.6215]}\end{array}$ & $\begin{array}{c}-0.7360 \\
(0.2686) \\
{[-0.2874]}\end{array}$ \\
\hline $\begin{array}{l}\chi^{2} \text { test } \\
\text { (p-value) }\end{array}$ & & & & $\begin{array}{c}52.30 \\
(0.0000) \\
\end{array}$ & $\begin{array}{c}12.05 \\
(0.0005) \\
\end{array}$ \\
\hline
\end{tabular}

Notes: Standard errors in parentheses (except where noted), marginal effects at the means in brackets. See notes to Table 2 for sample definitions. Regressions include all variables listed in previous tables, plus state-year interactions. The $\chi^{2}$ test is of the hypothesis that the coefficients on MED* and AFDC \% have equal and opposite signs, the restriction implicit in the use of GAIN \%. 
Table 5: AFDC Participation Models with State-Time Interactions, 1989-1992 March Current Population Surveys

\begin{tabular}{|c|c|c|c|c|c|}
\hline & (1) & (2) & (3) & (4) & 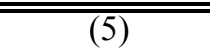 \\
\hline Labor force participation: & Yelowitz results & Replication & $\begin{array}{l}\text { Incorporating } \\
\text { gross test }\end{array}$ & $\begin{array}{l}\text { Allow diff. } \\
\text { effects for } \\
\text { AFDC and } \\
\text { Medicaid }\end{array}$ & $\begin{array}{c}\text { Diff. effects } \\
\text { incorporating } \\
\text { gross test }\end{array}$ \\
\hline \multicolumn{6}{|l|}{ All women: } \\
\hline GAIN \% & $\begin{array}{l}-0.6492 \\
(0.1714)\end{array}$ & $\begin{array}{c}-0.6040 \\
(0.1326) \\
{[-0.2043]}\end{array}$ & $\begin{array}{c}-0.1435 \\
(0.0991) \\
{[-0.0485]}\end{array}$ & & \\
\hline MED* & & & & $\begin{array}{c}-0.2819 \\
(0.1360) \\
{[-0.0953]}\end{array}$ & $\begin{array}{c}-0.0215 \\
(0.1019) \\
{[-0.0073]}\end{array}$ \\
\hline AFDC $\%$ & & & & $\begin{array}{c}1.8717 \\
(0.1738) \\
{[-.6325]}\end{array}$ & $\begin{array}{c}0.8751 \\
(0.1714) \\
{[0.2958]}\end{array}$ \\
\hline $\begin{array}{l}\chi^{2} \text { test } \\
\text { (p-value) }\end{array}$ & & & & $\begin{array}{c}130.88 \\
(0.0000)\end{array}$ & $\begin{array}{c}27.56 \\
(0.0000)\end{array}$ \\
\hline \multicolumn{6}{|l|}{ Ever married women: } \\
\hline GAIN \% & $\begin{array}{l}-0.9946 \\
(0.2543)\end{array}$ & $\begin{array}{c}-0.7733 \\
(0.2147) \\
{[-0.2154]}\end{array}$ & $\begin{array}{c}-0.1618 \\
(0.1505) \\
{[-0.0451]}\end{array}$ & & \\
\hline MED* & & & & $\begin{array}{l}-0.3644 \\
(0.2201) \\
{[-0.1011]}\end{array}$ & $\begin{array}{l}-0.0150 \\
(0.1547) \\
{[-0.0042]}\end{array}$ \\
\hline AFDC $\%$ & & & & $\begin{array}{c}1.9293 \\
(0.2528) \\
{[0.5354]}\end{array}$ & $\begin{array}{c}0.8996 \\
(0.2345) \\
{[0.2502]}\end{array}$ \\
\hline $\begin{array}{l}\chi^{2} \text { test } \\
\text { (p-value) }\end{array}$ & & & & $\begin{array}{c}78.20 \\
(0.0000)\end{array}$ & $\begin{array}{c}16.92 \\
(0.0000)\end{array}$ \\
\hline \multicolumn{6}{|l|}{ Never married women: } \\
\hline GAIN \% & $\begin{array}{l}-0.3537 \\
(0.2586)\end{array}$ & $\begin{array}{c}-0.4984 \\
(0.1811) \\
{[-0.1962]}\end{array}$ & $\begin{array}{l}-0.1462 \\
(0.1426) \\
{[-0.0575]}\end{array}$ & & \\
\hline MED* & & & & $\begin{array}{c}-0.1679 \\
(0.1865) \\
{[-0.0066]}\end{array}$ & $\begin{array}{c}-0.0259 \\
(0.1474) \\
{[-0.0102]}\end{array}$ \\
\hline AFDC $\%$ & & & & $\begin{array}{c}2.0081 \\
(0.2693) \\
{[0.7906]}\end{array}$ & $\begin{array}{c}0.9009 \\
(0.2724) \\
{[0.3546]}\end{array}$ \\
\hline $\begin{array}{l}\chi^{2} \text { test } \\
\text { (p-value) } \\
\end{array}$ & & & & $\begin{array}{c}58.34 \\
(0.0000) \\
\end{array}$ & $\begin{array}{c}10.62 \\
(0.0011) \\
\end{array}$ \\
\hline
\end{tabular}

Notes: Standard errors in parentheses (except where noted), marginal effects at the means in brackets. See notes to Table 2 for sample definitions. Regressions include all variables listed in previous tables, plus state-year interactions. The $\chi^{2}$ test is of the hypothesis that the coefficients on MED* and AFDC \% have equal and opposite signs, the restriction implicit in the use of GAIN \%. 
Table 6: Probit Models of Labor Force Participation, 1988-1996 March Current Population Surveys

\begin{tabular}{|c|c|c|c|c|}
\hline & (1) & (2) & (3) & (4) \\
\hline & "Replication" & $\begin{array}{c}\text { Incorporating gross } \\
\text { test }\end{array}$ & $\begin{array}{l}\text { Allow diff. effects for } \\
\text { AFDC and Medicaid }\end{array}$ & $\begin{array}{c}\text { Diff. effects } \\
\text { incorporating gross } \\
\text { test }\end{array}$ \\
\hline GAIN \% & $\begin{array}{c}0.2033 \\
(0.0480) \\
{[0.0685]}\end{array}$ & $\begin{array}{c}0.0575 \\
(0.0388) \\
{[0.0194]}\end{array}$ & & \\
\hline MED* & & & $\begin{array}{c}0.0554 \\
(0.0493) \\
{[0.0187]}\end{array}$ & $\begin{array}{l}-0.0092 \\
(0.0404) \\
{[-0.0031]}\end{array}$ \\
\hline AFDC $\%$ & & & $\begin{array}{l}-0.9362 \\
(0.0738) \\
{[-0.3150]}\end{array}$ & $\begin{array}{l}-0.3986 \\
(0.0703) \\
{[-0.1342]}\end{array}$ \\
\hline$\#$ kids $<$ age 6 & $\begin{array}{l}-0.1812 \\
(0.0194)\end{array}$ & $\begin{array}{l}-0.1894 \\
(0.0192)\end{array}$ & $\begin{array}{l}-0.1452 \\
(0.0196)\end{array}$ & $\begin{array}{l}-0.1831 \\
(0.0193)\end{array}$ \\
\hline Mother's age & $\begin{array}{c}0.0439 \\
(0.0076)\end{array}$ & $\begin{array}{c}0.0419 \\
(0.0076)\end{array}$ & $\begin{array}{c}0.0582 \\
(0.0077)\end{array}$ & $\begin{array}{c}0.0445 \\
(0.0076)\end{array}$ \\
\hline $\mathrm{Age}^{2} / 100$ & $\begin{array}{l}-0.0607 \\
(0.0110)\end{array}$ & $\begin{array}{l}-0.0578 \\
(0.0110)\end{array}$ & $\begin{array}{l}-0.0839 \\
(0.0111)\end{array}$ & $\begin{array}{l}-0.0620 \\
(0.0110)\end{array}$ \\
\hline Divorced & $\begin{array}{c}0.3472 \\
(0.0206)\end{array}$ & $\begin{array}{c}0.3474 \\
(0.0206)\end{array}$ & $\begin{array}{c}0.3501 \\
(0.0207)\end{array}$ & $\begin{array}{c}0.3476 \\
(0.0206)\end{array}$ \\
\hline Separated & $\begin{array}{c}0.1422 \\
(0.0213)\end{array}$ & $\begin{array}{c}0.1424 \\
(0.0213)\end{array}$ & $\begin{array}{c}0.1491 \\
(0.0214)\end{array}$ & $\begin{array}{c}0.1425 \\
(0.0213)\end{array}$ \\
\hline Black & $\begin{array}{l}-0.0671 \\
(0.0199)\end{array}$ & $\begin{array}{l}-0.0674 \\
(0.0199)\end{array}$ & $\begin{array}{l}-0.0668 \\
(0.0200)\end{array}$ & $\begin{array}{l}-0.0657 \\
(0.0200)\end{array}$ \\
\hline Central city & $\begin{array}{l}-0.2017 \\
(0.0177)\end{array}$ & $\begin{array}{l}-0.2011 \\
(0.0177)\end{array}$ & $\begin{array}{l}-0.2062 \\
(0.0178)\end{array}$ & $\begin{array}{l}-0.2021 \\
(0.0178)\end{array}$ \\
\hline Educ. & $\begin{array}{l}-0.0704 \\
(0.0151)\end{array}$ & $\begin{array}{l}-0.0703 \\
(0.0151)\end{array}$ & $\begin{array}{l}-0.0688 \\
(0.0151)\end{array}$ & $\begin{array}{l}-0.0691 \\
(0.0151)\end{array}$ \\
\hline Educ. $^{2}$ & $\begin{array}{c}0.0101 \\
(0.0007)\end{array}$ & $\begin{array}{c}0.0101 \\
(0.0007)\end{array}$ & $\begin{array}{c}0.0101 \\
(0.0007)\end{array}$ & $\begin{array}{c}0.0101 \\
(0.0007)\end{array}$ \\
\hline $\log -\mathrm{L}$ & -18922 & -18930 & -18835 & -18913 \\
\hline \# obs. & 36,628 & 36,628 & 36,628 & 36,628 \\
\hline $\begin{array}{l}\chi^{2} \text { test } \\
\text { (p-value) }\end{array}$ & & & $\begin{array}{l}172.13 \\
(0.000)\end{array}$ & $\begin{array}{c}33.82 \\
(0.000)\end{array}$ \\
\hline
\end{tabular}

Notes: Standard errors in parentheses (except where noted), marginal effects at the means in brackets. Sample includes single mothers ages 18-55 with a child under 15 from the 1988-1996 March Current Population Surveys. GAIN $\%=\max ($ MEDICAID $\%-$ AFDC $\%, 0)=$ MED*-AFDC $\%$. See text for descriptions of how MEDICAID \%, MED* and AFDC\% were constructed. Regressions also include dummies for state, year, family size, age of the youngest child, and age of the youngest child interacted with year. The $\chi^{2}$ test is of the hypothesis that the coefficients on MED* and AFDC \% have equal and opposite signs, the restriction implicit in the use of GAIN \%. 
Table 7: Probit Models of AFDC Participation, 1988-1996 March Current Population Surveys

\begin{tabular}{|c|c|c|c|c|}
\hline & $(1)$ & (2) & (3) & (4) \\
\hline & "Replication" & $\begin{array}{c}\text { Incorporating gross } \\
\text { test }\end{array}$ & $\begin{array}{l}\text { Allow diff. effects for } \\
\text { AFDC and Medicaid }\end{array}$ & $\begin{array}{c}\text { Diff. effects } \\
\text { incorporating gross } \\
\text { test }\end{array}$ \\
\hline GAIN \% & $\begin{array}{l}-0.1943 \\
(0.0483) \\
{[-0.0665]}\end{array}$ & $\begin{array}{l}-0.0440 \\
(0.0388) \\
{[-0.0151]}\end{array}$ & & \\
\hline MED* & & & $\begin{array}{l}-0.0382 \\
(0.0495) \\
{[-0.0130]}\end{array}$ & $\begin{array}{c}0.0462 \\
(0.0403) \\
{[0.0158]}\end{array}$ \\
\hline AFDC $\%$ & & & $\begin{array}{c}0.9634 \\
(0.0734) \\
{[0.3294]}\end{array}$ & $\begin{array}{c}0.5124 \\
(0.0701) \\
{[0.1752]}\end{array}$ \\
\hline$\#$ kids $<$ age 6 & $\begin{array}{c}0.2114 \\
(0.0194)\end{array}$ & $\begin{array}{c}0.2192 \\
(0.0193)\end{array}$ & $\begin{array}{c}0.1748 \\
(0.0196)\end{array}$ & $\begin{array}{c}0.2107 \\
(0.0193)\end{array}$ \\
\hline Mother's age & $\begin{array}{l}-0.0093 \\
(0.0078)\end{array}$ & $\begin{array}{l}-0.0072 \\
(0.0078)\end{array}$ & $\begin{array}{l}-0.0241 \\
(0.0079)\end{array}$ & $\begin{array}{l}-0.0107 \\
(0.0078)\end{array}$ \\
\hline $\mathrm{Age}^{2} / 100$ & $\begin{array}{l}-0.0100 \\
(0.0113)\end{array}$ & $\begin{array}{l}-0.0131 \\
(0.0112)\end{array}$ & $\begin{array}{c}0.0139 \\
(0.0114)\end{array}$ & $\begin{array}{l}-0.0074 \\
(0.0113)\end{array}$ \\
\hline Divorced & $\begin{array}{l}-0.3320 \\
(0.0203)\end{array}$ & $\begin{array}{l}-0.3322 \\
(0.0203)\end{array}$ & $\begin{array}{l}-0.3356 \\
(0.0204)\end{array}$ & $\begin{array}{l}-0.3327 \\
(0.0203)\end{array}$ \\
\hline Separated & $\begin{array}{l}-0.1974 \\
(0.0213)\end{array}$ & $\begin{array}{l}-0.1977 \\
(0.0213)\end{array}$ & $\begin{array}{l}-0.2048 \\
(0.0213)\end{array}$ & $\begin{array}{l}-0.1978 \\
(0.0213)\end{array}$ \\
\hline Black & $\begin{array}{c}0.2074 \\
(0.0198)\end{array}$ & $\begin{array}{c}0.2078 \\
(0.0198)\end{array}$ & $\begin{array}{c}0.2085 \\
(0.0199)\end{array}$ & $\begin{array}{c}0.2060 \\
(0.0199)\end{array}$ \\
\hline Central city & $\begin{array}{c}0.1711 \\
(0.0177)\end{array}$ & $\begin{array}{c}0.1704 \\
(0.0177)\end{array}$ & $\begin{array}{c}0.1758 \\
(0.0177)\end{array}$ & $\begin{array}{c}0.1717 \\
(0.0177)\end{array}$ \\
\hline Educ. & $\begin{array}{c}0.1703 \\
(0.0150)\end{array}$ & $\begin{array}{c}0.1701 \\
(0.0150)\end{array}$ & $\begin{array}{c}0.1695 \\
(0.0151)\end{array}$ & $\begin{array}{c}0.1687 \\
(0.0150)\end{array}$ \\
\hline Educ. $^{2}$ & $\begin{array}{l}-0.0139 \\
(0.0007)\end{array}$ & $\begin{array}{l}-0.0139 \\
(0.0007)\end{array}$ & $\begin{array}{l}-0.0138 \\
(0.0007)\end{array}$ & $\begin{array}{l}-0.0138 \\
(0.0709)\end{array}$ \\
\hline $\log -\mathrm{L}$ & -19345 & -19353 & -19247 & -19320 \\
\hline \# obs. & 36,628 & 36,628 & 36,628 & 36,628 \\
\hline $\begin{array}{l}\chi^{2} \text { test } \\
\text { (p-value) }\end{array}$ & & & $\begin{array}{l}194.21 \\
(0.000)\end{array}$ & $\begin{array}{c}64.34 \\
(0.000)\end{array}$ \\
\hline
\end{tabular}

Notes: Standard errors in parentheses (except where noted), marginal effects at the means in brackets. See notes to Table 6 for sample definitions. Regressions include all variables listed in previous tables, plus state-year interactions. The $\chi^{2}$ test is of the hypothesis that the coefficients on MED* and AFDC \% have equal and opposite signs, the restriction implicit in the use of GAIN \%. 
Table 8: Labor Force Participation Models with State-Time Interactions, 1988-1996 March Current Population Surveys

\begin{tabular}{|c|c|c|c|c|}
\hline & $(1)$ & $(2)$ & $(3)$ & $(4)$ \\
\hline Labor force participation: & "Replication" & $\begin{array}{c}\text { Incorporating gross } \\
\text { test }\end{array}$ & $\begin{array}{l}\text { Allow diff. effects } \\
\text { for AFDC and } \\
\text { Medicaid }\end{array}$ & $\begin{array}{c}\text { Diff. effects } \\
\text { incorporating gross } \\
\text { test }\end{array}$ \\
\hline \multicolumn{5}{|l|}{ All women: } \\
\hline GAIN \% & $\begin{array}{c}0.4016 \\
(0.0637) \\
{[0.1345]}\end{array}$ & $\begin{array}{c}0.1301 \\
(0.0551) \\
{[0.0436]}\end{array}$ & & \\
\hline MED* & & & $\begin{array}{c}0.1122 \\
(0.0667) \\
{[0.0376]}\end{array}$ & $\begin{array}{c}0.0280 \\
(0.0575) \\
{[0.0094]}\end{array}$ \\
\hline AFDC $\%$ & & & $\begin{array}{l}-1.4307 \\
(0.0963) \\
{[-0.4787]}\end{array}$ & $\begin{array}{l}-0.6807 \\
(0.1042) \\
{[-0.2278]}\end{array}$ \\
\hline $\begin{array}{l}\chi^{2} \text { test } \\
\text { (p-value) }\end{array}$ & & & $\begin{array}{c}206.30 \\
(0.0000)\end{array}$ & $\begin{array}{c}38.86 \\
(0.0000)\end{array}$ \\
\hline \multicolumn{5}{|l|}{ Ever married women: } \\
\hline GAIN \% & $\begin{array}{c}0.5507 \\
(0.0976) \\
{[0.1529]}\end{array}$ & $\begin{array}{c}0.2397 \\
(0.0830) \\
{[0.0665]}\end{array}$ & & \\
\hline MED* & & & $\begin{array}{c}0.2211 \\
(0.1030) \\
{[0.0613]}\end{array}$ & $\begin{array}{c}0.1311 \\
(0.0863) \\
{[0.0364]}\end{array}$ \\
\hline AFDC $\%$ & & & $\begin{array}{l}-1.4155 \\
(0.1306) \\
{[-0.3921]}\end{array}$ & $\begin{array}{l}-0.7774 \\
(0.1434) \\
{[-0.2157]}\end{array}$ \\
\hline $\begin{array}{l}\chi^{2} \text { test } \\
\text { (p-value) }\end{array}$ & & & $\begin{array}{c}101.98 \\
(0.0000)\end{array}$ & $\begin{array}{c}21.24 \\
(0.0000)\end{array}$ \\
\hline \multicolumn{5}{|l|}{ Never married women: } \\
\hline GAIN \% & $\begin{array}{c}0.2764 \\
(0.0901) \\
{[0.1076]}\end{array}$ & $\begin{array}{c}0.0444 \\
(0.0794) \\
{[0.0173]}\end{array}$ & & \\
\hline MED* & & & $\begin{array}{l}-0.0266 \\
(0.0947) \\
{[-0.0104]}\end{array}$ & $\begin{array}{l}-0.0602 \\
(0.0836) \\
{[-0.0235]}\end{array}$ \\
\hline AFDC $\%$ & & & $\begin{array}{c}-1.5482 \\
(0.1547) \\
{[-0.6027]}\end{array}$ & $\begin{array}{c}-0.6055 \\
(0.1619) \\
{[-0.2357]}\end{array}$ \\
\hline $\begin{array}{l}\chi^{2} \text { test } \\
\text { (p-value) }\end{array}$ & & & $\begin{array}{r}103.06 \\
(0.0000) \\
\end{array}$ & $\begin{array}{c}15.86 \\
(0.0001) \\
\end{array}$ \\
\hline
\end{tabular}

Notes: Standard errors in parentheses (except where noted), marginal effects at the means in brackets. See notes to Table 6 for sample definitions. Regressions include all variables listed in previous tables, plus state-year interactions. The $\chi^{2}$ test is of the hypothesis that the coefficients on MED* and AFDC \% have equal and opposite signs, the restriction implicit in the use of GAIN \%. 
Table 9: AFDC Participation Models with State-Time Interactions, 1988-1996 March Current Population Surveys

\begin{tabular}{|c|c|c|c|c|}
\hline & $(1)$ & 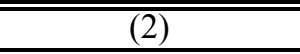 & $(3)$ & $(4)$ \\
\hline Labor force participation: & "Replication" & $\begin{array}{c}\text { Incorporating gross } \\
\text { test }\end{array}$ & $\begin{array}{l}\text { Allow diff. effects } \\
\text { for AFDC and } \\
\text { Medicaid }\end{array}$ & $\begin{array}{c}\text { Diff. effects } \\
\text { incorporating gross } \\
\text { test }\end{array}$ \\
\hline \multicolumn{5}{|l|}{ All women: } \\
\hline GAIN \% & $\begin{array}{l}-0.3704 \\
(0.0641) \\
{[-0.1262]}\end{array}$ & $\begin{array}{l}-0.1044 \\
(0.0555) \\
{[-0.0356]}\end{array}$ & & \\
\hline MED* & & & $\begin{array}{l}-0.0470 \\
(0.0674) \\
{[-0.0160]}\end{array}$ & $\begin{array}{l}0.0303 \\
(0.0579) \\
{[0.0103]}\end{array}$ \\
\hline AFDC $\%$ & & & $\begin{array}{c}1.5112 \\
(0.0969) \\
{[0.5145]}\end{array}$ & $\begin{array}{l}0.8406 \\
(0.1051) \\
{[0.2862]}\end{array}$ \\
\hline $\begin{array}{l}\chi^{2} \text { test } \\
\text { (p-value) }\end{array}$ & & & $\begin{array}{c}251.54 \\
(0.0000)\end{array}$ & $\begin{array}{c}68.49 \\
(0.0000)\end{array}$ \\
\hline \multicolumn{5}{|l|}{ Ever married women: } \\
\hline GAIN \% & $\begin{array}{l}-0.5472 \\
(0.0992) \\
{[-0.1540]}\end{array}$ & $\begin{array}{l}-0.1579 \\
(0.0838) \\
{[-0.0444]}\end{array}$ & & \\
\hline MED* & & & $\begin{array}{l}-0.1579 \\
(0.1047) \\
{[-0.0443]}\end{array}$ & $\begin{array}{l}-0.0062 \\
(0.0870) \\
{[-0.0017]}\end{array}$ \\
\hline AFDC $\%$ & & & $\begin{array}{c}1.5766 \\
(0.1325) \\
{[0.4423]}\end{array}$ & $\begin{array}{c}0.9388 \\
(0.1457) \\
{[0.2637]}\end{array}$ \\
\hline $\begin{array}{l}\chi^{2} \text { test } \\
\text { (p-value) }\end{array}$ & & & $\begin{array}{c}140.34 \\
(0.0000)\end{array}$ & $\begin{array}{c}43.36 \\
(0.0000)\end{array}$ \\
\hline \multicolumn{5}{|l|}{ Never married women: } \\
\hline GAIN \% & $\begin{array}{c}-0.2440 \\
(0.0900) \\
{[-0.0958]}\end{array}$ & $\begin{array}{c}-0.0745 \\
(0.0797) \\
{[-0.0293]}\end{array}$ & & \\
\hline MED* & & & $\begin{array}{c}0.0991 \\
(0.0952) \\
{[0.0389]}\end{array}$ & $\begin{array}{c}0.0719 \\
(0.0840) \\
{[0.0283]}\end{array}$ \\
\hline AFDC $\%$ & & & $\begin{array}{l}1.6423 \\
(0.1541) \\
{[0.6451]}\end{array}$ & $\begin{array}{c}0.8543 \\
(0.1623) \\
{[0.3356]}\end{array}$ \\
\hline $\begin{array}{l}\chi^{2} \text { test } \\
\text { (p-value) }\end{array}$ & & & $\begin{array}{r}126.71 \\
(0.0000) \\
\end{array}$ & $\begin{array}{c}30.54 \\
(0.0000) \\
\end{array}$ \\
\hline
\end{tabular}

Notes: Standard errors in parentheses (except where noted), marginal effects at the means in brackets. See notes to Table 6 for sample definitions. Regressions include all variables listed in previous tables, plus state-year interactions. The $\chi^{2}$ test is of the hypothesis that the coefficients on MED* and AFDC $\%$ have equal and opposite signs, the restriction implicit in the use of GAIN \%. 
Figure 1: Medicaid Expansions Induce An Individual to Leave Welfare

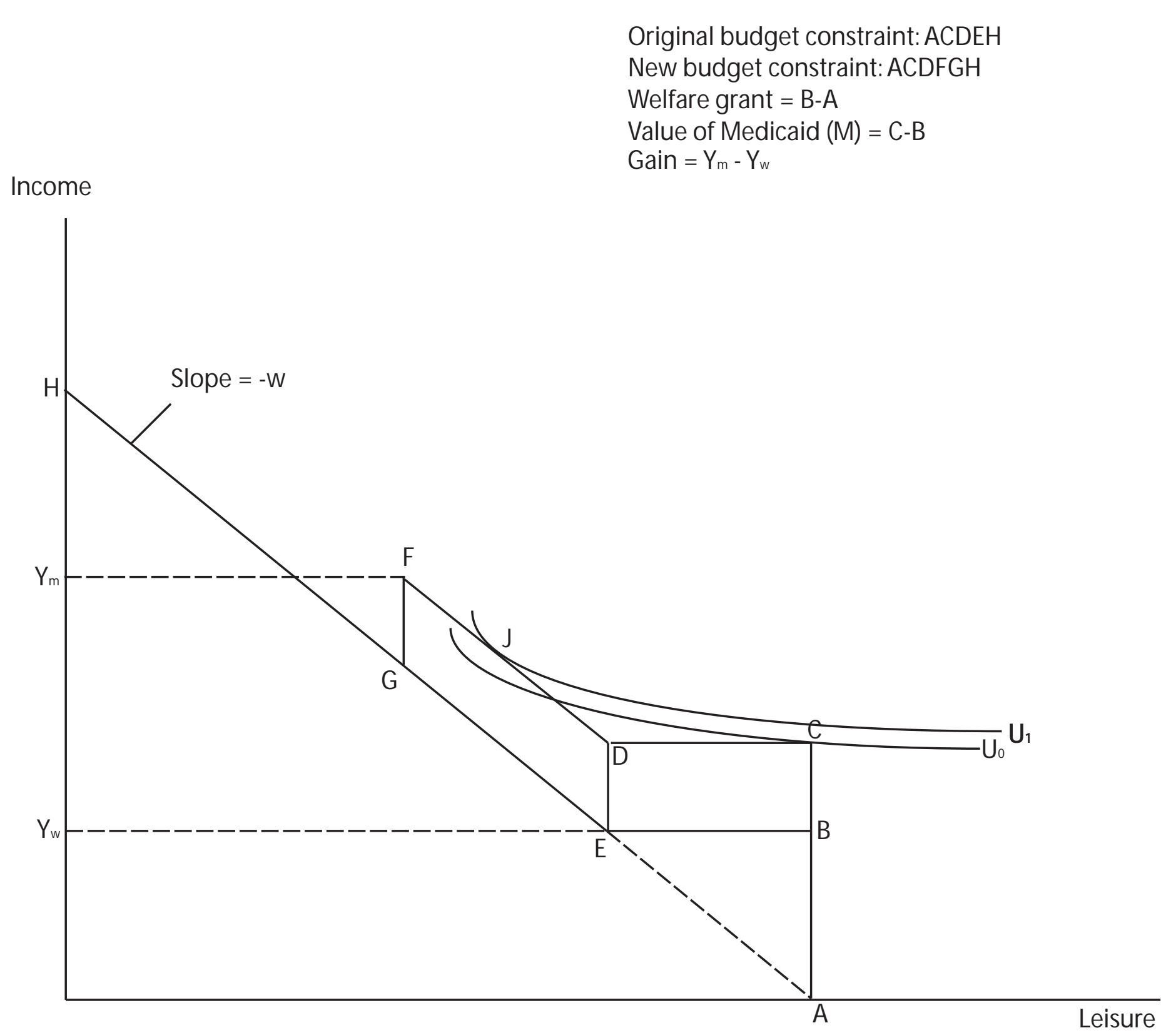


Figure 2: Increasing Welfare Grant Induces Someone to Enter Welfare

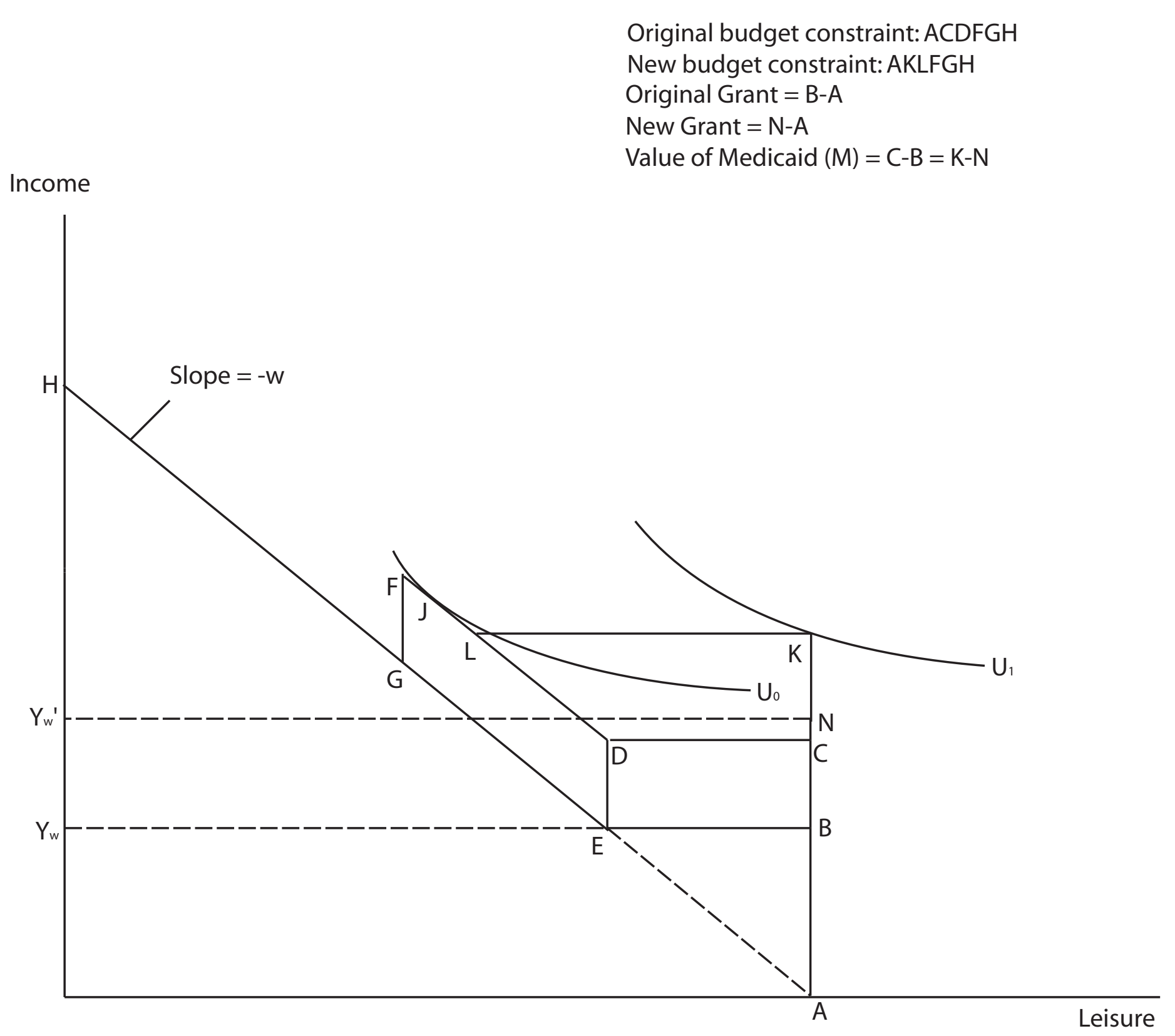


Figure 3: Increasing Medicaid Limit Induces the Individual to Leave Welfare

Original Budget Constraint:ACDFGH

New Budget Constraint:ACDF'G'H

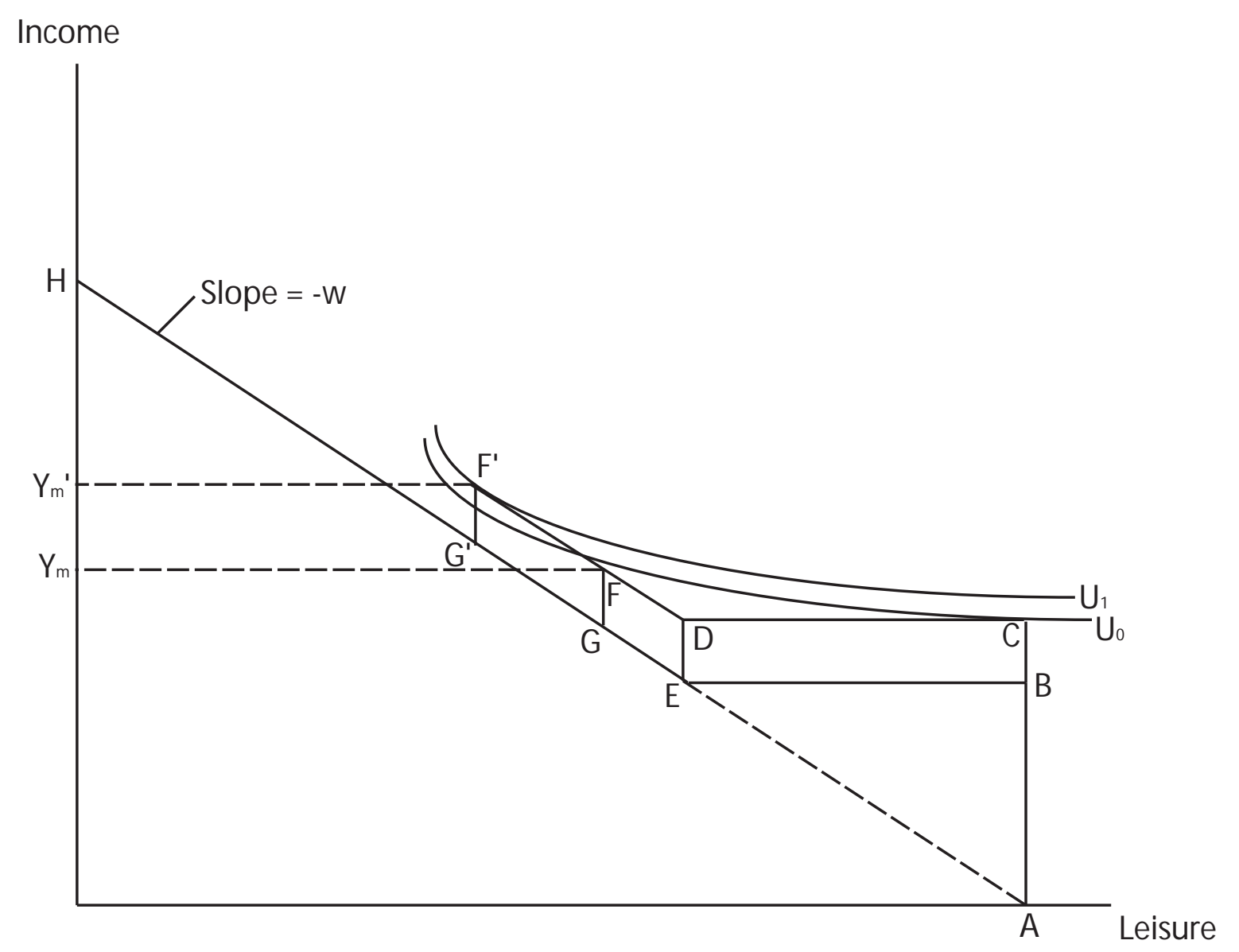


Income Figure 4: Increasing the Wage Induces

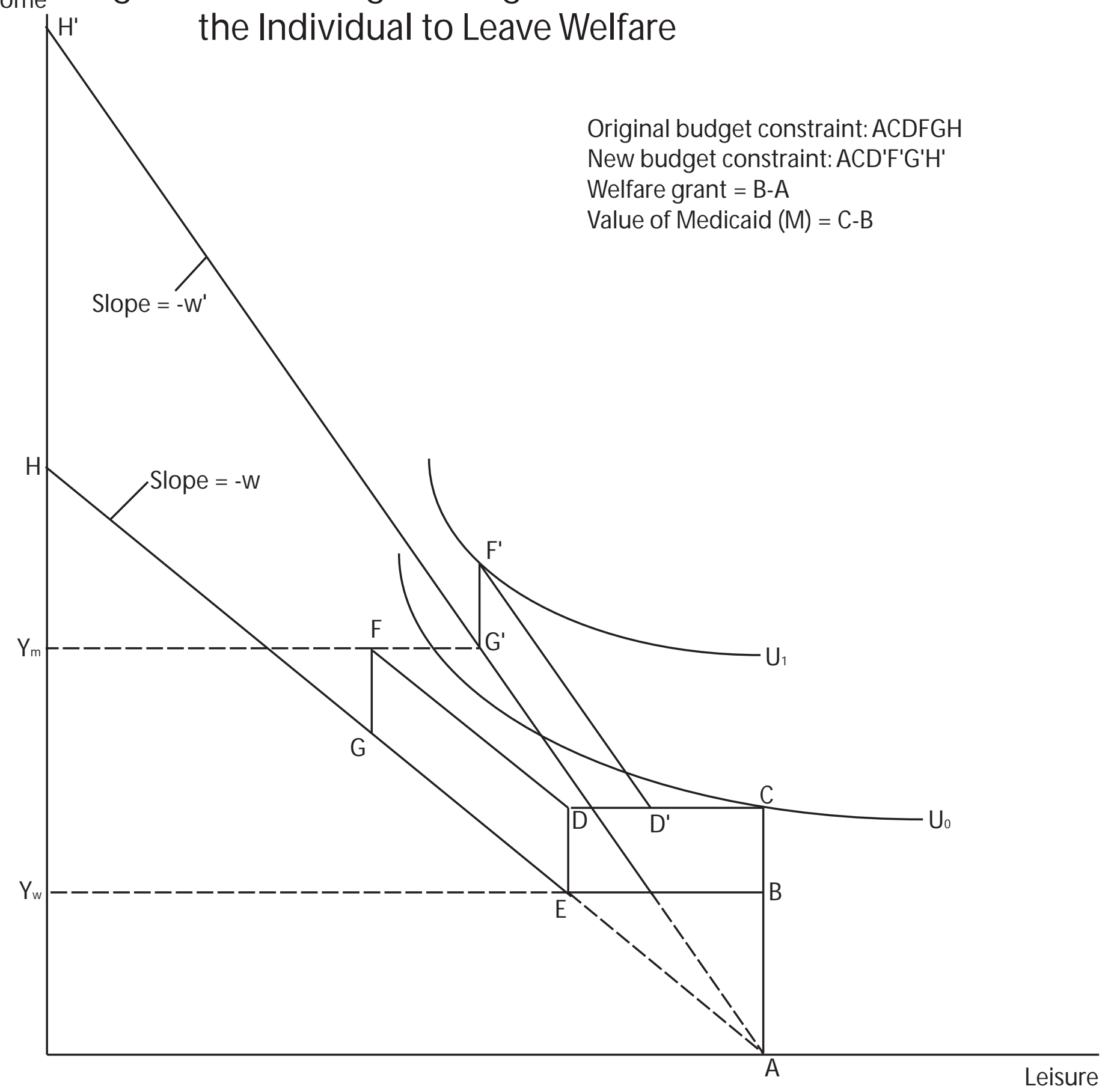


Figure 5: Increasing Benefits Holding Gain Constant Induces the Individual to Enter Welfare

Original budget constraint: ACDFGH

New budget constraint: AKD'F'G'H

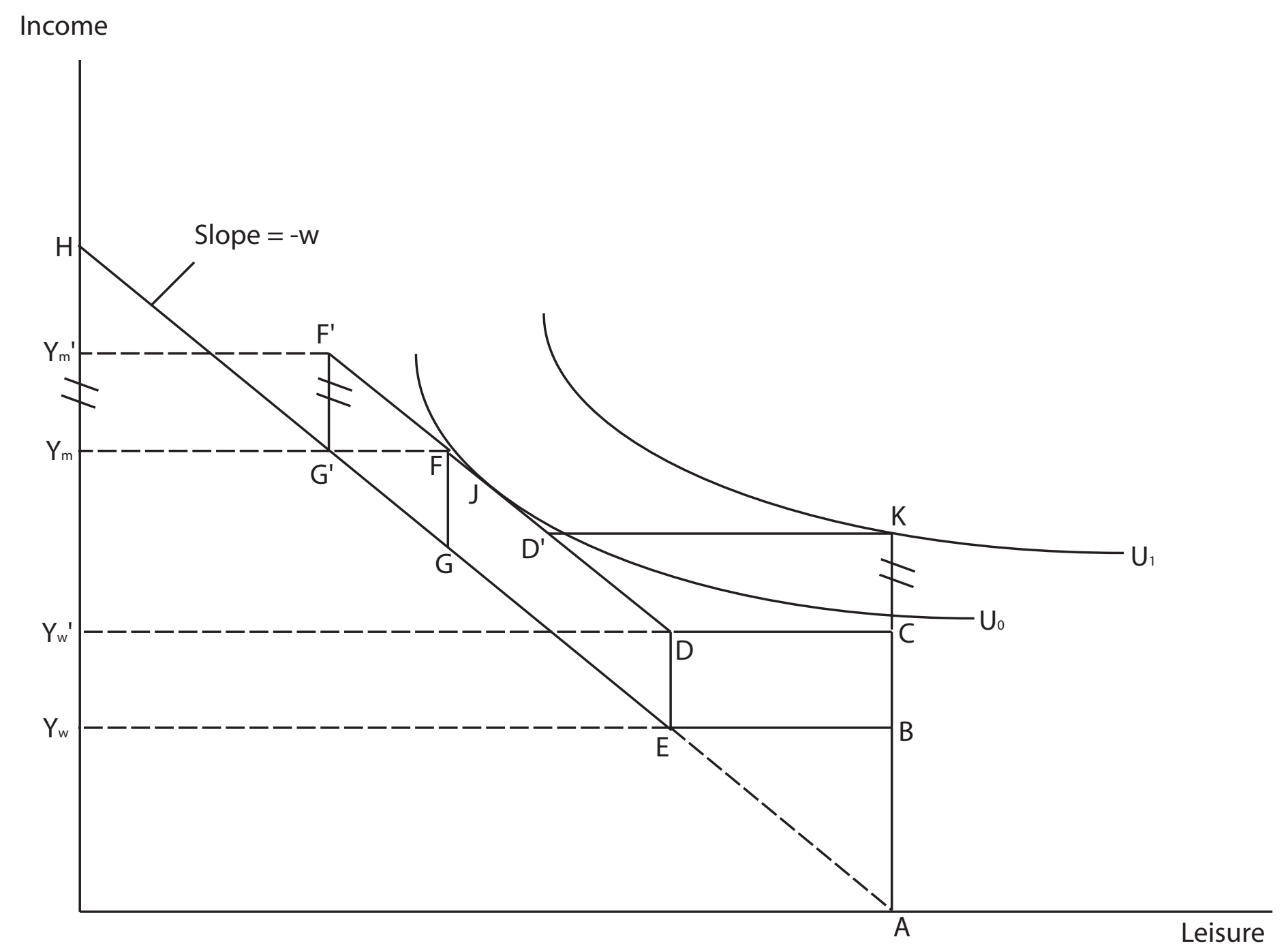

